4. Ковач І.В. Карієсрезистентність та склад ротової рідини у дітей / І.В.Ковач, І.М. Щербина, В.Д. Каюкова / Медичні перспективи. - 2013. - №4(1). - С. 103 - 105.

5. Tanaca K. Dental caries and allergia disordesin children / K.Tanaca, Y.Migake, M. Arakava // Asthma. - 2008. Vol.45, №9. - P. 795-797.

\section{REFERENCES}

1. Okushko V.R. Osnovy fiziologii zuba [Fundamentals of tooth physiology]. Tiraspol, I.P.U. 2005; 237.

2. Anomshoa J, Vierf A.R. Caries is Assosiated with Epilepsy. Eur J Dent. 2009;3(4):297-303.
3. Paganini M., Bianco R. Dental caries status and salivary properties of adolescents. Jnt I Paediatr Dent. 2011;21(3):185-91.

4. Kovach I.V., Shcherbyna I.M., Kaiukova V.D. Caries resistance and oral fluid in children. Medychni perspektyvy. 2013;18(4)1:103-5.

5. Tanaca K., Migake Y., Arakava M. Dental caries and allergia disordesin children. Asthma. 2008;45(9):795-7.

Надійшла 23.01.19

УДК 616-07:616.314.17-008.1+616.314-089.23(048)〉

DOI https://doi.org/10.35220/2523-420X/2019.1.9

\title{
Н.В. Гутарова
}

Державний заклад «Дніпровська медична академія МО3 України»

\section{РОЛЬ МАТРИКСНОЇ МЕТАЛОПРОТЕІНАЗИ-8 В ДІАГНОСТИЦІ ЗАПАЛЬНИХ ЗА- ХВОРЮВАНЬ ПАРОДОНТУ ПРИ ОРТОДОНТИЧНОМУ ЛІКУВАННІ НЕЗНІМНОЮ АПАРАТУРОЮ}

Одним із основних етіологічних чинників ризику та патогенетичних механізмів розвитку запальних захворювань пародонту являсться патологія прикусу або зубощелепні аномалії. Відомо, щуо високий відсоток ускладнень, а саме, розвиток запальних захворювань в тканинах пародонту виявляються під час або після ортодонтичного лікування.

Мета даного дослідження. Вивчення матриксної металопротеінази-8 у пацієнтів з хронічним катаральним гінгівітом в динаміці ортодонтичного лікування незнімною апаратурою.

Матеріали та методи дослідження. Нами було проведено дослідження 34 молодих осіб у віиі від 16 до 25 років, з яких 21 дівчина (61,8\%) та 13 хлопчів (38,2\%), яким проводилось ортодонтичне лікування за допомогою незнімних конструкцій. У всіх пацієнтів було діагностовано хронічний катаральний гінгівіт, який виник під час ортодонтичного лікування.

Результати дослідження та їх обговорення. В ротовій рідині пацієнтів із зубо-щелепними аномаліями та незнімними конструкціями ортодонтичних апаратів в порожнині рота на початку ортодонтичного лікування були встановлені такі значення матриксної металопротеінази - 8 (1,85 \pm 0,09 нг/мл), які вірогідно відрізнялись від значення у здорових людей без патології тканин пародонту (0,27 \pm 0,01 нг/мл), щуо можна пов'язати, на нашу думку, із запаленням в тканинах пародонта, яке виникає на тлі зубощелепних аномалій та іншої ортодонтичної патології.

Проведені нами дослідження показали, щзо при використанні незнімних ортодонтичних апаратів виникає травмування тканин пародонту і ие може привести до виникнення хронічного катарального гінгівіту. Крім того важлива роль у виникненні запальних процесів в тканинах пародонту належить також різним зубощзелепним аномаліям в порожнині рота.

Ключові слова: матрична металопротеіназа-8, хронічний катаральний гінгівіт, ортодонтичне лікування, ротова рідина.

\section{Н.В. Гутарова}

Государственно учреждение «Днепропетровская медицинская академия МО3 Украины»

\section{РОЛЬ МАТРИКСНОЙ МЕТАЛЛОПРОТЕИНАЗЫ-8 В ДИАГНОСТИКЕ ВОСПАЛИ- ТЕЛЬНЫХ ЗАБОЛЕВАНИЙ ПАРОДОНТА ПРИ ОРТОДОНТИЧЕСКОМ ЛЕЧЕНИИ НЕСЬЕМНОЙ АППАРАТУРОЙ}

Одним из основных этиологических факторов риска и патогенетических механизмов развития воспалительных заболеваний пародонта является патология прикуса или зубочелюстные аномалии. Известно, что высокий процент осложнений, а именно, развитие воспалительных заболеваний в тканях пародонта выявляются во время или после ортодонтического лечения. 
Цель данного исследования. Изучение матриксной металлопротеиназы-8 у пациентов с хроническим катаральным гингивитом в динамике ортодонтического лечения несъемной аппаратурой.

Материалы и методы исследования. Нами были проведены исследования 34 молодых лиц в возрасте от 16 до 25 лет, из которых 21 девушка (61,8\%) и 13 парней (38,2\%); которым проводилось ортодонтическое лечение с помощью несъемных конструкиий. У всех паџиентов был диагностирован хронический катаральный гингивит, возникиий во время ортодонтического лечения.

Результаты исследования и их обсуждение. В ротовой жидкости пациентов с зубочелюстными аномалиями и несъемными конструкциями ортодонтических аппаратов в полости рта в начале ортодонтического лечения были установлены следующие значения матриксной металлопротеиназы - 8 (1,85 \pm 0,09 нг/мл), достоверно отличавшиеся от значений у здоровых людей без патологии тканей пародонта (0,27 \pm 0,01 нг/мл), и это можно связать, по нашему мнению, с воспалением в тканях пародонта, которое возникает на фоне зубочелюстных аномалий и другой ортодонтической патологии.

Проведенные нами исследования показали, что при использовании несъемных ортодонтических аппаратов возникает травмирование тканей пародонта и это может привести к возникновению хронического катарального гингивита. Кроме того важная роль в возникновении воспалительных процессов в тканях пародонта принадлежит также различным зубочелюстным аномалиям в полости рта.

Ключевые слова: матричная металлопротеиназа-8, хронический катаральный гингивит, ортодонтическое лечение, ротовая жидкость.

\section{N.V. Gutarova}

State institution " Dnepropetrovsk medical Academy of the Ministry of health of Ukraine»

\section{THE ROLE OF MATRIX METALLOPROTEINASE-8 IN THE DIAGNOSIS OF INFLAMMATORY PERIODONTAL DISEASES IN ORTHODONTIC TREATMENT WITH FIXED EQUIPMENT}

One of the main etiological risk factors and pathogenetic mechanisms for the development of inflammatory periodontal diseases is malocclusion or dental abnormalities. It is known that a high percentage of complications, namely, the development of inflammatory diseases in periodontal tissues are detected during or after orthodontic treatment.

The purpose of this study. Study of matrix metalloproteinase-8 in patients with chronic catarrhal gingivitis in the dynamics of orthodontic treatment with fixed equipment.

Materials and methods of research. We conducted studies of 34 young people aged 16 to 25 years, including 21 girls $(61.8 \%)$ and 13 boys (38.2\%), who underwent orthodontic treatment using fixed structures. All patients were diagnosed with chronic catarrhal gingivitis that occurred during orthodontic treatment.

The results of the study and their discussion. The following values of matrix metalloproteinase $-8(1.85 \pm 0.09$ $\mathrm{ng} / \mathrm{ml}$ ) were found in the oral fluid of patients with dental anomalies and fixed structures of orthodontic devices in the oral cavity at the beginning of orthodontic treatment, which significantly differed from the values in healthy people without periodontal tissue pathology $(0.27 \pm 0.01 \mathrm{ng} / \mathrm{ml})$, and this can be associated, in our opinion, with inflammation in periodontal tissues, which occurs against the background of dental anomalies and other orthodontic pathology.

Our research has shown that when using fixed orthodontic devices, periodontal tissue injury occurs and this can lead to the occurrence of chronic catarrhal gingivitis. In addition, an important role in the occurrence of inflammatory processes in periodontal tissues also belongs to various dental anomalies in the oral cavity.

Key word: matrix metalloproteinase-8, chronic catarrhal gingivitis, orthodontic treatment, oral fluid.

3 початку XX століття і до $60-\mathrm{x}$ років причину розвитку захворювань пародонту бачили в загальній патології і порушеннях оклюзії. У 60 70-ті роки минулого століття на перше місце була поставлена проблема зубної бляшки. Накопичення епідеміологічних і клінічних даних зумовило формування іншої гіпотези: у розвитку i прогресуванні захворювань пародонта істотна роль належить певним чинникам ризику [1-2].

Одним із основних етіологічних чинників ризику та патогенетичних механізмів розвитку запальних захворювань пародонту являється патологія прикусу або зубощелепні аномалії [3-4]. Відомо, що високий відсоток ускладнень, а саме, розвиток запальних захворювань в тканинах пародонту виявляються під час або після ортодонтичного лікування [5-6].

Тому багаточисельними дослідженнями в останні роки науковці роблять спроби пошуку нових маркерів, які б дозволили прогнозувати перебіг захворювання на етапі його діагностики, що дало б змогу займатись превентивним лікуванням [7]. В останні роки одним із таких маркерів являються матриксні металопротеінази, які можуть гідролізувати основні білки в позаклітинному просторі [8-11] Матриксна мететалопротеіназа-8 (ММР-8) вважається одною із ведучих маркерів запалення. 
Мета даного дослідження. Вивчення матриксної металопротеінази-8 у пацієнтів 3 хронічним катаральним гінгівітом в динаміці ортодонтичного лікування незнімною апаратурою.

Матеріали та методи дослідження. Нами було проведено дослідження 34 молодих осіб у віці від 16 до 25 років, з яких 21 дівчина (61,8 \%) та 13 хлопців (38,2 \%), яким проводилось ортодонтичне лікування за допомогою незнімних конструкцій. У всіх пацієнтів було діагностовано хронічний катаральний гінгівіт, який виник під час ортодонтичного лікування. Всі обстежені молоді люди були учнями або студентами навчальних закладів та звернулись за консультацією і лікуванням до стоматологічної клініки.

Біохімічні дослідження проводилися в ротовій рідині пацієнтів. Аналіз досліджень ротової рідини проводили на початку ортодонтичного лікування та через 3 і 6 місяців після встановлення незнімної ортодонтичної апаратури. Ротову рідину збирали вранці натще. Кількісне визначення людської загальної матриксної металлопротеінази-8 (ММР-8) в ротовій рідині проводили методом імуноферментного аналізу за допомогою набору Quantikine, який визначає як профермент, так і активні форми людської ММР8. Діапазон вимірювання - 0,06-10 нг/мл. Аналітична чутливість - 0,06 нг/мл.

Статистична обробка даних виконувалася 3 використанням загальноприйнятих непараметричних методів за допомогою програми MS Excel i ліцензійної статистичної програми Biostat. Достовірними вважалися відмінності між групами при ймовірності помилки менше $5 \%(\mathrm{p}<0,05)$.

Результати дослідження та ӥх обговорення. В ротовій рідині пацієнтів із ЗЩА та незнімними конструкціями ортодонтичних апаратів в порожнині рота на початку ортодонтичного лікування були встановлені такі значення матриксної металопротеінази - $8(1,85 \pm 0,09$ нг/мл), які вірогідно відрізнялись від значення у здорових людей без патології тканин пародонту $(0,27 \pm$ 0,01 нг/мл), що можна пов'язати, на нашу думку, iз запаленням в тканинах пародонта, яке виникає на тлі зубощелепних аномалій та іншої ортодонтичної патології.

Аналіз цифрових даних показав, що значення ММР-8 у пацієнтів, яким проводилось ортодонтичне лікування незнімною апаратурою, зростають (табл.).

Таблиця

\section{Показники концентрації ММР-8 в ротовій рідині у здорових осіб та паціснтів під час ортодонтичного лікування, нг/мл (M \pm m)}

\begin{tabular}{|c|c|c|c|c|}
\hline \multicolumn{1}{|c|}{ Показник } & Здорові & $\begin{array}{c}\text { На початку ліку- } \\
\text { вання }\end{array}$ & $\begin{array}{c}\text { Через 3 міс. ліку- } \\
\text { вання }\end{array}$ & Через 6 міс. лікування \\
\hline MМР8 & $0,27 \pm 0,01$ & $1,85 \pm 0,09$ & $3,39 \pm 0,17 *$ & $5,96 \pm 0,31^{*}$ \\
\hline
\end{tabular}

Пр и м і $т$ ка: *- відмінності достовірні $(\mathrm{p}<0,05)$ порівняно із здоровими

Так, через 3 місяці після початку ортодонтичного лікування значення концентрація ММР-8 достовірно збільшувалась і складали $3,39 \pm 0,17$ нг/мл, що в 1,8 рази більше в порівнянні з даними на початку лікування та здоровими особами такого ж віку. Через 6 місяців ортодонтичного лікування кількісне значення ММР-8 в ротовій рідині збільшувалось ще більше та становило $5,96 \pm 0,31$ нг/мл відповідно, що в 3,2 рази більше в порівнянні з вихідними даними на початку лікування та в 1,8 рази більше в порівнянні з попереднім дослідженням, яке проводилось нами через 3 місяці після встановлення незнімної ортодонтичної апаратури.

Проведені нами дослідження показали, що при використанні незнімних ортодонтичних апаратів виникає травмування тканин пародонту i це може привести до виникнення хронічного ка- тарального гінгівіту. Крім того важлива роль у виникненні запальних процесів в тканинах пародонту належить також різним зубо-щелепним аномаліям в порожнині рота.

На нашу думку, достовірне збільшення рівня MМР-8 в ротовій рідині за наявності етіологічних факторів ризику являються тим маркером, за допомогою якого можна прогнозувати розвиток запалення в тканинах пародонту та виникнення хронічного катарального гінгівіту.

Таким чином, представлені дані кількісної оцінки ММР-8 в порожнині рота переконливо свідчать про те, що у обстежених пацієнтів, які знаходяться на ортодонтичному лікуванні, спостерігається зростання вивчаємого біохімічного маркеру. Отримані результати дослідження свідчать про те, що у досліджуваних нами пацієнтів, які мають незнімну ортодонтичну апаратуру в 
порожнині рота, виникає хронічний катаральний гінгівіт на тлі ортодонтичного лікування. В той же час, вивчаємий показник був найбільшим через 6 місяців після початку ортодонтичного лікування, що свідчить про залежність інтенсивності запалення в тканинах пародонту від терміну лікування. На нашу думку, це, можливо, обумовлено зниженням секреції ротової рідини та збільшенням ii в'язкості і кількості мікрофлори в порожнині рота при ортодонтичному лікуванні.

\section{REFERENCES}

1. Borysenko A. V., Antonenko M. Yu., Lynovytska, L. V., et al. Stomatolohichni zakhvoriuvannia: terapevtychna stomatolohiia [Stomatological diseases: therapeutic stomatology]. Kyiv: Medytsyna. 2017:664 [in Ukrainian].

2. Jenkins W.M., Papapanou P.N. Epidemiology of periodontal disease in children and adolescents. Periodontal. 2000;26:16-32.

3. Albandar, J.M. Global risk factors and risk indicators for periodontal diseases. Periodontol-2000. 2002;29:177-206.

4. Neely A.L., Holford T.R., Loe H. The natural history of periodontol disease in man. Risk factors for progression of attachment loss in individuals receiving no oral health care. J. Periodontol. 2011;28(72):1006-1015.

5. Nazir, M. A. Prevalence of periodontal disease, its association with systemic diseases and prevention. International Journal of Health Sciences. 2017;11(2):72-80.
6. Righolt, A. J., Jevdjevic. M., Marcenes, W., Listl S. Global-, Regional-, and Country-Level Economic Impacts of Dental Diseases in 2015. Journal of Dental Research. 2018;97(5):501-507. doi: 10.1177/0022034517750572.

7. Tonetti, M. S., Jepsen, S., Jin, L., Otomo-Corgel J. Impact of the global burden of periodontal diseases on health, nutrition and wellbeing of mankind: A call for global action. Journal of Clinical Periodontology. 2017;44(5):456-462. doi: $10.1111 /$ jcpe. 12732 .

8. Zhigulina, V. V., Rumyantsev, V. A. Matrix metalloproteinases in periodontal disease. Vestnik Tverskogo gosudarstvennogo universiteta. Seriya «Khimiya». 2016;3:134144.

9. Franco C., Patricia H. R., Timo, S., Claudia, B. Marcela H. Matrix metalloproteinases as regulators of periodontal inflammation. International Journal of Molecular Sciences. 2017;18(2):pii: E440. doi: 10.3390/ijms18020440.

10. Markelova, E. V., Zdor, V. V., Romanchuk, A. L., Birko O. N. Matrix metalloproteinases: on their relationship with cytokine system, diagnostic and prognostic potential. Immunopatologiya, alergologiya, infektologiya. 2016;2:11-22. doi: 10.14427/jipai.2016.2.23.

11. Qian, L., Xuedong, Z., Yaping, F., Tengyu, Y., Songtao, W., Yu, Y., et al. Analysis of salivary protease spectrum in chronic periodontitis. Hua Xi Kou Qiang Yi Xue Za Zhi. 2017;35(1):37-42. doi: 10.7518/hxkq.2017.01.005.

Надійшла 04.02.19

616-036.22:[613.64+616-053.5]

DOI https://doi.org/10.35220/2523-420X/2019.1.10

*С.В. Скульская к. мед. н., С.А. Шнайдер, д. мед. н.

*Национальная медицинская академия последипломного образования имени П. Л. Шупика

Государственное учреждение «Институт стоматологии и челюстно-лицевой хирургии Национальной академии медицинских наук Украины»

\section{СОСТОЯНИЕ ТВЕРДЫХ ТКАНЕЙ ЗУБОВ У ДЕТЕЙ Г. БЕЛАЯ ЦЕРКОВЬ, ПРОЖИ- ВАЮЩИХ В ЗОНАХ РАЗЛИЧНОЙ АНТРОПОГЕННОЙ НАГРУЗКИ ПО ДАННЫМ ЗА 2015-2016 УЧЕБНЫЙ ГОД}

Актуальность. Повышенная антропогенная нагрузка оказывает неблагоприятное воздействие на стоматологическое здоровье детей: повышенная распространенность кариеса зубов, дефектов эмали и частота встречаемости заболеваний пародонта. Оиенки состояния твердых тканей детей г. Белая Церковь практически не проводилось.

Целью данной работы было изучение данных состояния твердых тканей зубов у детей г. Белая Церковь, проживающих в зонах различной антропогенной нагрузки, полученных в ходе обследования в 2015-2016 учебном годy.

Материалы и методы. Было произведено 16054 осмотра детей, проживаюших в г. Белая Церковь в зонах различной антропогенной нагрузки в 2015-2016 учебном году. Состояние твёрдых тканей зубов оценивалось с помощью индексов КПУз, КПУп, и их составляющих. Также определялось количество детей с кариесом, пульпитом и периодонтитом. Активность кариеса определялась по классификации предложенной Виноградовой T. $\Phi$. 